\title{
DEFLECTION OF REINFORCED CONCRETE BEAMS STRENGTHENED WITH CFRP
}

\author{
Tomas Skuturna1, Mykolas Daugevičius ${ }^{2}$, Juozas Valivonis ${ }^{3}$ \\ ${ }^{1,2,3}$ Department of Reinforced Concrete and Masonry Structures, Vilnius Gediminas Technical University, \\ Saulètekio ave 11, 10223 Vilnius, Lithuania
}

E-mail: '1tomas.skuturna@vgtu.lt (correspondingauthor); ${ }^{2}$ mykolas.daugevicius@vgtu.lt; ${ }^{3}$ juozas.valivonis@vgtu.lt

\begin{abstract}
This paper presents the results of an experimental study to investigate the deflection of reinforced concrete beams strengthened with external CFRP reinforcement. The influence of anchoring of external reinforcement was investigated. CFRP reinforcement was anchored in three different ways. Steel clamps, fibre wraps and steel pins were used for anchoring. Also different prepressing levels and different areas of steel clamps were used. The analysis of results of experimental research shows that anchoring of external reinforcement affects the performance and deflection of the strengthened reinforced concrete beams.
\end{abstract}

Keywords: reinforced concrete beams, strengthening, CFRP, deflection.

\section{Introduction}

Reinforced concrete structures can be strengthened with CFRP reinforcement. Such method is quite widely applied and is supposed to be efficient and convenient for the purpose of strengthening (Lamanna et al. 2004; Bank, Arora 2007; Li et al. 2008; Skuturna et al. 2008; Valivonis, Skuturna 2007; David et al. 2003; Bulavs et al. 2005; Duthinh, Starnes 2004; Chahrour, Soudki 2005; Ekenel et al. 2006; Ferrier, Hamelin 2002; Fayyadh, Razak 2012; Ceroni, Pecce 2007; Trapko, Trapko 2012; Buyukozturk et al. 2004; Yail et al. 2013; Smith, Teng 2002a; Smith, Teng 2002b; Hajsadeghi et al. 2011; Heffernan, Erki 2004; Xie, Hu 2013; Thomsen et al. 2004; Hsu et al. 2003; Harries et al. 2007). This strengthening technique, due to such excellent qualities of CFRP as high tensile strength, resistance to aggressive environment, and low weight, has a lot of advantages in comparison to other commonly applied techniques.

It is well known that the bond between concrete and CFRP is not stiff and due to shear strains external reinforcement may slip (Chen, Pan 2006; Pham, Al-Mahaidi 2007; Perera et al. 2004; Ueda, Jianguo 2005; Camli, Binici 2007; Lu et al. 2006; Casas, Pascual 2007; Schilde, Seim 2007; Iovinella et al. 2013; Ferracuti et al. 2007; Subramaniam et al. 2007; Mostofinejad, Shameli 2013; Wang et al. 2007; Freddi, Savoia 2008; Biolzi et al. 2013; Yuan et al. 2004; Ramos et al. 2004; Dai et al. 2005; Ramos et al. 2006; Pan, Leung 2007a; Saxena et al. 2008; Niu, Wu 2006; Pham et al. 2006; Pan, Leung 2007b; Ferrier et al. 2006; Mazzotti et al. 2008). So the deflection of the strengthened structure increases and the effect of strengthening decreases. The bond between concrete and CFRP is influenced by a few factors such as dimensions of concrete structure and CFRP, properties of the materials, and the way of anchoring external reinforcement. Only integrated performance of CFRP and strengthened structure can ensure effective strengthening. This can be reached by using additional anchoring of external reinforcement.

\section{Experimental work}

For experimental research 18 beams were produced. The beams were divided into two groups: B1 and B2. The focus of the first group was on investigation of the influence of different ways of anchoring. For the second group the focus was on investigation of the influence of different pre-pressing levels and different areas of steel clamps.

During the research all beams were tested in four-point bending (Fig. 1 and Fig. 2).

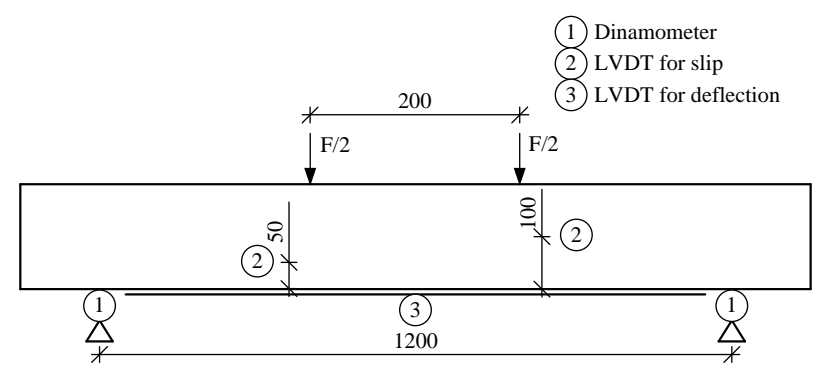

Fig. 1. Scheme of test setup and instrumentation.

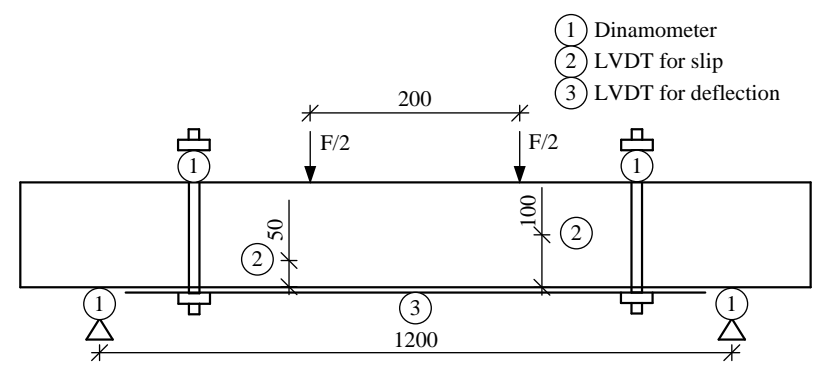

Fig. 2. Scheme of test setup and instrumentation (of beams whose external reinforcement is anchored with steel clamps).

The dimensions of the beams were $100 \mathrm{~mm}$ wide, $200 \mathrm{~mm}$ deep and 1,500 $\mathrm{mm}$ long. The span of the beams was $1,200 \mathrm{~mm}$. The tension zone and the compression zone of beams were reinforced with $2 \varnothing 8$ and $2 \varnothing 6 \mathrm{~mm}$ steel bars respectively (Fig. 3). 


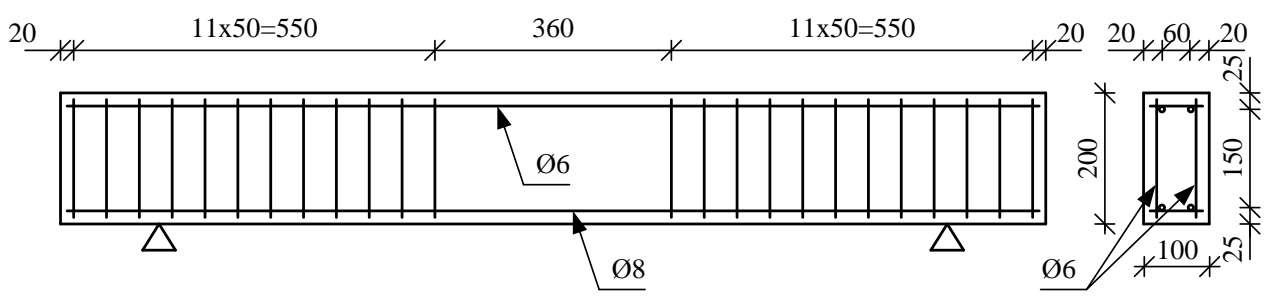

Fig. 3. Reinforcing details of B beams.

The shear spans of the beams were reinforced with $2 \varnothing 6 \mathrm{~mm}$ stirrups spaced at $50 \mathrm{~mm}$ along the beam. The width of the carbon fibre strip was $100 \mathrm{~mm}$ and its crosssectional area was $16.8 \mathrm{~mm}^{2}$.

The concrete strength class was C30/37. All internal reinforcement was standard steel reinforcing bars with nominal yield strength of $500 \mathrm{MPa}$. The strength in tension of carbon fibre was $3850 \mathrm{MPa}$.

Beams BN1-1 and BN2-1 were control specimens without external reinforcement (Fig. 4 (a)). Beams BR1-2, BR1-3 and BR2-2 (Fig. 4 (b)) were strengthened with CFRP but external reinforcement was not additionally anchored. For the rest of the beams external reinforcement was anchored in different ways. Steel pins were used in beams BA1-4 and BA1-5 (Fig. 4 (c)). For beams BS1-6 and BS1-7 external reinforcement was anchored with $U$ wraps of carbon strips (Fig. 4 (d)).

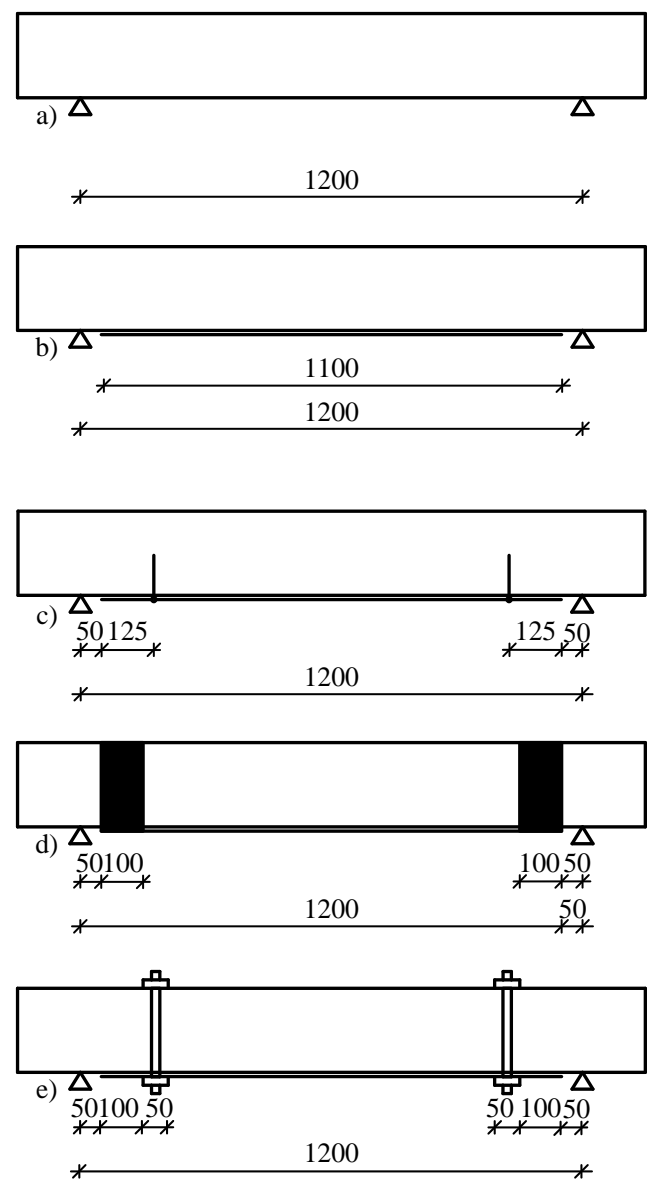

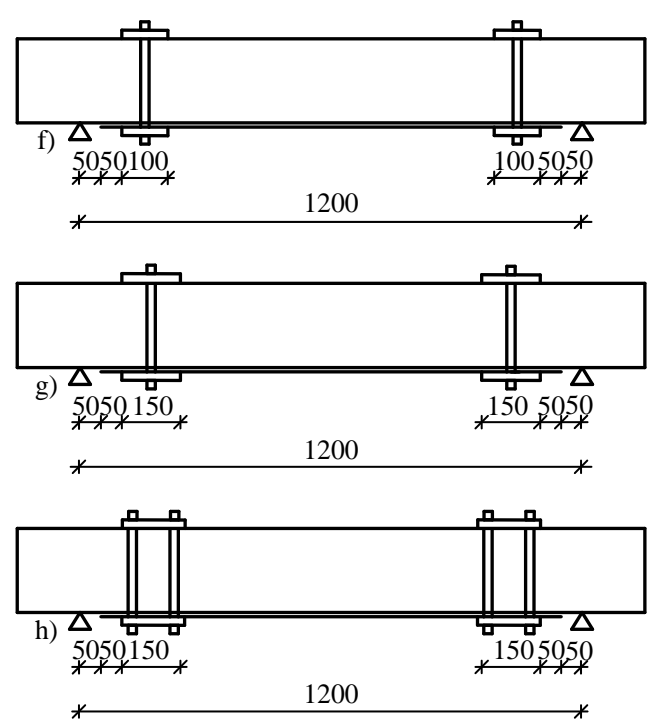

Fig. 4. Strengthening details of beams: a) control beams BN1-1, BN2-1; b) beams BR1-2, BR1-3, BR2-2; c) beams BA1-4, BA1-5; d) beams BS1-6, BS1-7; e) beams BC1-8, BC1-9, BC2-3, BC2-4, BC2-5, BC2-6; f) BC2-7; g) BC2-8; h) BC2-9.

Table 1. The way of anchoring external reinforcement

\begin{tabular}{c|c|c}
\hline Beam & Anchoring & Note \\
\hline BA1-4 & Steel pin & - \\
BA1-5 & Steel pin & - \\
BS1-6 & U wrap & - \\
BS1-7 & U wrap & Clamp area $50 \mathrm{~cm}^{2}$ \\
BC1-8 & Steel clamp & Clamp area $50 \mathrm{~cm}^{2}$ \\
BC1-9 & Steel clamp & Clamp area $50 \mathrm{~cm}^{2}, 1 \mathrm{MPa}$ \\
BC2-3 & Steel clamp & Clamp area $50 \mathrm{~cm}^{2}, 1 \mathrm{MPa}$ \\
BC2-4 & Steel clamp & Clamp area $50 \mathrm{~cm}^{2}, 0,5 \mathrm{MPa}$ \\
BC2-5 & Steel clamp & Clamp area $50 \mathrm{~cm}^{2}, 2 \mathrm{MPa}$ \\
BC2-6 & Steel clamp & Clamp area $100 \mathrm{~cm}^{2}$ \\
BC2-7 & Steel clamp & Clamp area $150 \mathrm{~cm}^{2}, 2$ bolts \\
BC2-8 & Steel clamp & Clamp area $150 \mathrm{~cm}^{2}, 4$ bolts \\
BC2-9 & Steel clamp
\end{tabular}

The external reinforcement was anchored with steel clamps in beams BC1-8 and BC1-9 (Fig. 4 (e)). The areas of steel clamps were $50 \mathrm{~cm}^{2}$. For B2 group of beams steel clamps areas were $50 \mathrm{~cm}^{2}$ (BC2-3, BC2-4, BC2-5, BC2-6) (Fig. 4 (e)), $100 \mathrm{~cm}^{2}$ (BC2-7) (Fig. 4 (f)), $150 \mathrm{~cm}^{2}$ (BC2-8, BC2-9) (Fig. $4(\mathrm{~g}, \mathrm{~h})$ ). Also for B2 group of beams different prepressing levels of steel clamps were applied $0.5 \mathrm{MPa}(\mathrm{BC} 2-5), 1 \mathrm{MPa}(\mathrm{BC} 2-3, \mathrm{BC} 2-4)$ and $2 \mathrm{MPa}$ (BC2-6). 


\section{Experimental results}

It is expedient to distinguish three stages in the performance of reinforced concrete flexural structures strengthened with external CFRP reinforcement: performance of the member prior to the opening of first cracks; from the opening of cracks till the appearance of yield stresses in the steel bar reinforcement; when steel bar reinforcement yields until beam failure.

The graphs of the load-deflection relation for beam with the best anchorage (when steel clamps were used) beam without additional anchoring and control beam are presented in Fig. 5.

Analysis of graphs expressing load-deflection relationships (Fig. 5) indicates that in the first stage deflections of all beams were almost of the same value. After the appearance of normal cracks, deflections began to increase significantly, and the beams entered the second stage of performance. Stiffness of the beams is reduced due to cracks in the beams. At this stage of performance deflections grow with the load. Also the effect of strengthening can be seen in this stage, the deflection of the control beam is bigger than deflection of the strengthened beams. When the value of stress in the steel bar reinforcement reaches the value of the yield stress, the load-deflection curves demonstrate that beams enter the next stage. At this stage the effect of additional anchoring is seen. The beam external reinforcement of which is additionally anchored deflects less than the strengthened beam without anchors.

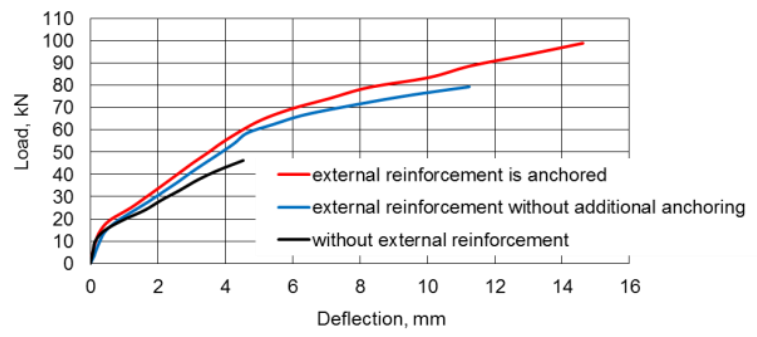

Fig. 5. Experimental deflection of beams.

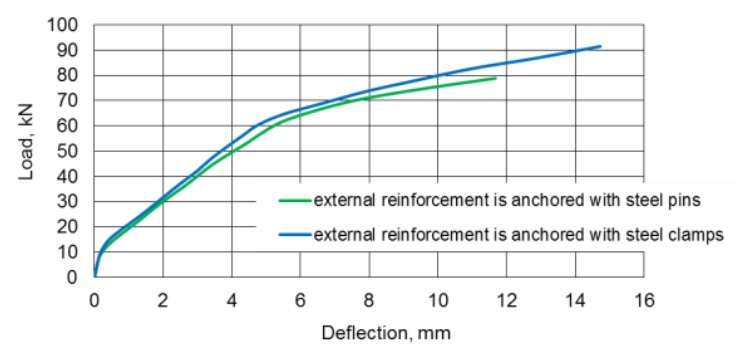

Fig. 6. Experimental deflection of beams BA1 (anchored with steel pins) and $\mathrm{BC} 1$ (anchored with steel clamps).

The performed analysis of experimental results shows that deflection of beams (which CFRP reinforcement anchored with steel pins) in all performance stages is by 10 percent bigger than that of the beams whose external reinforcement was anchored with steel clamps or $\mathrm{U}$ wrap (Fig. 6 and Fig. 7). In all stages of performance deflections of beams BC1 and BS1 (CFRP anchored with steel clamps and $\mathrm{U}$ wrap respectively) are similar.

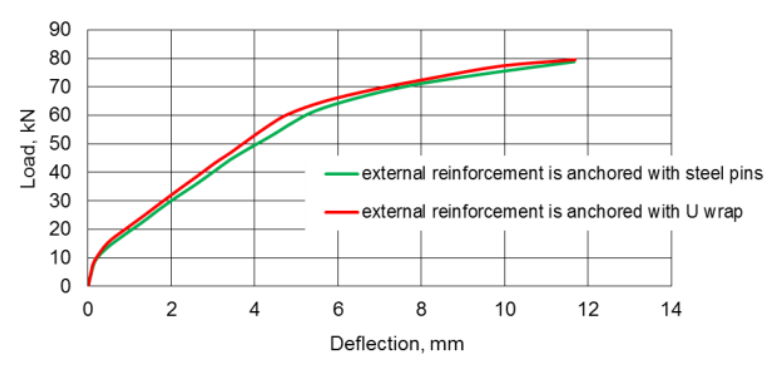

Fig. 7. Experimental deflection of beams BA1 (anchored with steel pins) and BS1 (anchored with U wrap).

Experimental research shows that different levels (0.5 MPa, $1 \mathrm{MPa}, 2 \mathrm{MPa})$ of pre-pressing the anchorage area of external reinforcement with metal clamps do not have significant influence on the deflections of strengthened beams (Fig. 8).

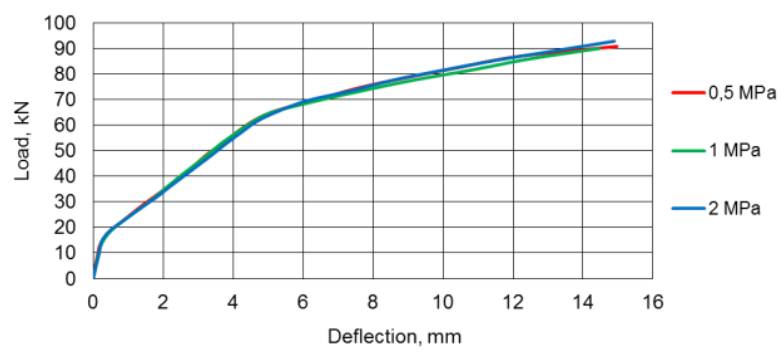

Fig. 8. Experimental deflection of beams BC2-4 (pre-pressing level $1 \mathrm{MPa}$ ), BC2-5 (pre-pressing level $0.5 \mathrm{MPa}$ ), BC2-6 (pre-pressing level $2 \mathrm{MPa}$ ).

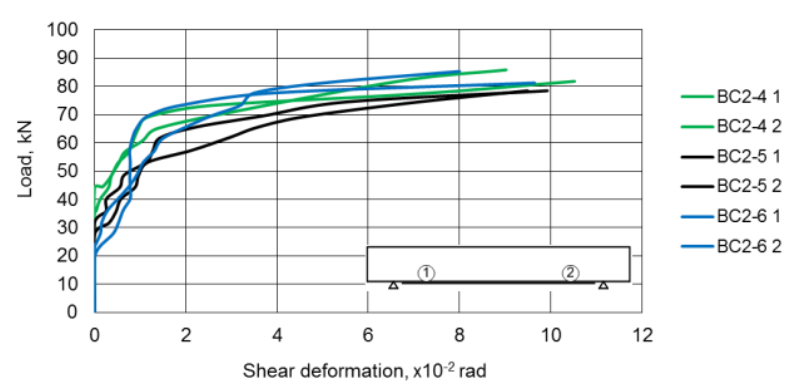

Fig. 9. Load-shear curves of beams BC2-4, BC2-5, BC2-6.

Analysis of the graph (Fig. 9) shows that when shear deformations of the bond grow, deflections of beams and pre-pressing levels of steel clamps also grow (Fig. 10). When the stress of steel bar reinforcement reaches and exceeds yield stress, the shear deformations increase significantly because the major part of the stress increment is resisted by CFRP reinforcement. Deflection of beams also increases significantly. The results of research show that pre-pressing level of steel clamps before failure increases by several times (Fig. 10). This can be explained by the fact that chocks have formed in the steel clamps due to shear deformations and deflection. 


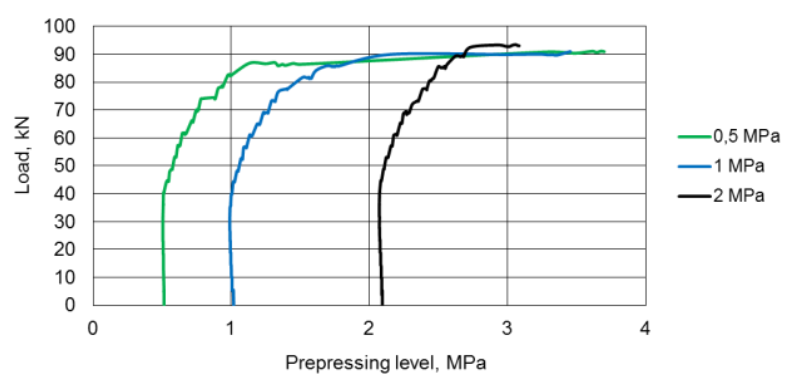

Fig. 10. Pre-pressing level in steel clamps.

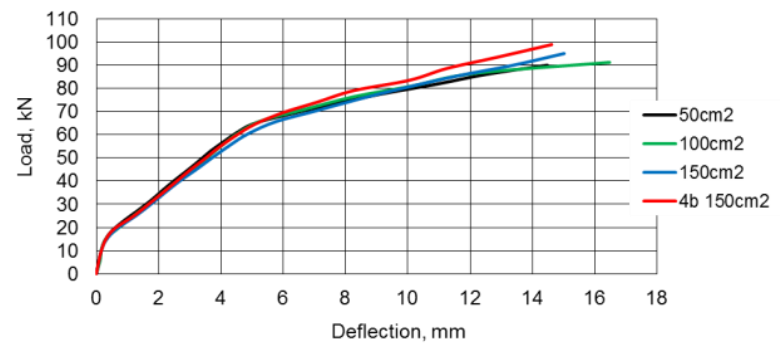

Fig. 11. Experimental deflection of beams BC2-4 (steel clamp area $50 \mathrm{~cm}^{2}$ ), BC2-7 (steel clamp area $100 \mathrm{~cm}^{2}$ ), BC2-8 (steel clamp area $150 \mathrm{~cm}^{2}$ ), BC2-9 (4 bolts, steel clamp area $150 \mathrm{~cm}^{2}$ ).

The research also shows that increasing of the area of pre-pressing with metal clamps does not have a significant influence on the load-carrying capacity of the beams strengthened with external CFRP reinforcement, however, it influences deflections of the strengthened beams (Fig. 11). The bigger the prepressing area, the smaller are the deflections.

\section{Conclusions}

Experimental research shows the influence of the type of additional anchorage of external reinforcement on the performance of the strengthened beams. The most effective way of anchorage is anchoring with steel clamps. When external reinforcement is anchored in this way, shear strains in the bond between external carbon fibre reinforcement and the strengthened member reduce as a result of which deflections decrease in comparison to the beams whose carbon fibre is not additionally anchored.

Research indicates that when external reinforcement is anchored with steel clamps, the level and area of pre-pressing of fibre do not have any influence on the load-carrying capacity of the strengthened beams. The recommended minimum area and level of pre-pressing of fibre in order to receive the maximum effectiveness of strengthening with respect to the deflection are $50 \mathrm{~cm}^{2}$ and $1 \mathrm{MPa}$. It has been established that the bigger the area of CFRP pre-pressing, the higher the stiffness of the bond between concrete and external reinforcement, the smaller are the deflections of the strengthened beams.

\section{References}

Bank, L. C.; Arora, D., 2007. Analysis and design of RC beams with mechanically fastened FRP (MF-FRP) strips. Composite Structures, 79(2), pp. 180-191. http://dx.doi.org/10.1016/j.compstruct.2005.12.001

Biolzi, L.; Ghittoni, C.; Fedele, R.; Rosati, G., 2013. Experimental and theoretical issues in FRP-concrete bonding. Construction and Building Materials, 41, pp. 182-190. http://dx.doi.org/10.1016/j.conbuildmat.2012.11.082

Bulavs, F.; Radinsh, I.; Tirans, N., 2005. Improvement of capacity in bending by the use of FRP layers on RC beams. Journal of Civil Engineering and Management, 11(3), pp. $169-174$.

http://dx.doi.org/10.1080/13923730.2005.9636347

Buyukozturk, O.; Gunes, O.; Karaca, E., 2004. Progress on understanding debonding problems in reinforced concrete and steel members strengthened using FRP composites. Construction and Building Materials, 18(1), pp. 9-19. http://dx.doi.org/10.1016/S0950-0618(03)00094-1

Camli, U. S.; Binici, B., 2007. Strength of carbon fiber reinforced polymers bonded to concrete and masonry. Construction and Building Materials, 21(7), pp. 1431-1446. http://dx.doi.org/10.1016/j.conbuildmat.2006.07.003

Casas, J. R.; Pascual, J., 2007. Debonding of FRP in bending: simplified model and experimental validation. Construction and Building Materials, 21(10), pp. 1940-1949. http://dx.doi.org/10.1016/j.conbuildmat.2006.05.055

Ceroni, F.; Pecce, M., 2007. Cracking behaviour of RC beams externally strengthened with emerging materials. Construction and Building Materials, 21(4), pp. 736-745. http://dx.doi.org/10.1016/j.conbuildmat.2006.06.013

Chahrour, A.; Soudki, K., 2005. Flexure response of reinforced concrete beams strengthened with end anchored partially bonded carbon fiber reinforced polymer strips. Journal of Composites for Construction, 9(2), pp. 170-177. http://dx.doi.org/10.1061/(ASCE)1090-0268(2005)9:2(170)

Chen, J. F.; Pan, W. K., 2006. Three dimensional stress distribution in FRP-to-concrete bond test specimens. Construction and Building Materials, 20(1-2), pp. 46-58. http://dx.doi.org/10.1016/j.conbuildmat.2005.06.037

Dai, J.; Ueda, T.; Sato, Y., 2005. Development of the nonlinear bond stress-slip model of fiber reinforced plastics sheetconcrete interfaces with a simple method. Journal of Composites for Construction, 9(1), pp. 52-62. http://dx.doi.org/10.1061/(ASCE)1090-0268(2005)9:1(52)

David, E.; Ragneau, E.; Buyle-Bodin, F., 2003. Experimental analysis of flexural behaviour of externally bonded CFRP reinforced concrete structures. Materials and Structures, 36(4), pp.238-241. http://dx.doi.org/10.1007/BF02479617

Duthinh, D.; Starnes, M., 2004. Strength and ductility of concrete beams reinforced with carbon fiber reinforced polymer plates and steel. Journal of Composites for Construction, 8(1), pp. 59-69. http://dx.doi.org/10.1061/(ASCE)1090-0268(2004)8:1(59)

Ekenel, M.; Rizzo, A.; Myers, J. J.; Nanni, A., 2006. Flexural fatigue behavior of reinforced concrete beams strengthened with FRP fabric and precured laminate systems. Journal of Composites for Construction, 10(5), pp. 433-442. http://dx.doi.org/10.1061/(ASCE)1090-0268(2006)10:5(433)

Fayyadh, M. M.; Razak, H. A., 2012. Assessment of effectiveness of CFRP repaired RC beams under different damage levels based on flexural stiffness. Construction and Building Materials, 37, pp. 125-134.

http://dx.doi.org/10.1016/j.conbuildmat.2012.07.021 
Ferracuti, B.; Savoia, M.; Mazzotti, C., 2007. Interface law for FRP-concrete delamination. Composite Structures, 80(4), pp. 523-531. http://dx.doi.org/10.1016/j.compstruct.2006.07.001

Ferrier, E.; Avril, S.; Hamelin, P.; Vautrin, A. 2006. Mechanical behavior of RC beams reinforced by externally bonded CFRP sheets. Materials and Structure, 36(8), pp. 522-529. http://dx.doi.org/10.1007/BF02480829

Ferrier, E.; Hamelin, P., 2002. Long-time concrete-composite interface characterization for reliability prediction of RC beam strengthened with FRP. Materials and Structures 35(9), pp. 564-572. http://dx.doi.org/10.1007/BF02483125

Freddi, F.; Savoia, M., 2008. Analysis of FRP-concrete debonding via boundary integral equations. Engineering Fracture Mechanics, 75(6), pp. 1666-1683. http://dx.doi.org/10.1016/j.engfracmech.2007.05.016

Hajsadeghi, M.; Alaee, F. J.; Shahmohammadi, A., 2011. Investigation on behaviour of square/rectangular reinforced concrete columns retrofitted with FRP jacket. Journal of Civil Engineering and Management, 17(3), pp. 400-408. http://dx.doi.org/10.3846/13923730.2011.594155

Harries, K. A.; Reeve, B.; Zorn, A., 2007. Experimental evaluation of factors affecting monotonic and fatigue behavior of FRP to concrete bond. ACI Structures Journal 104(6), pp. 667-674.

Heffernan, P. J.; Erki, M. A., 2004. Fatigue behavior of reinforced concrete beams strengthened with carbon fiber reinforced plastic laminates, Journal of Composites for Construction, 8(2), pp. 132-140.

http://dx.doi.org/10.1061/(ASCE)1090-0268(2004)8:2(132)

Hsu, C. T. T.; Punurai, W.; Bian, H.; Jia, Y., 2003. Flexural strengthening of reinforced concrete beams using carbon fibre reinforced polymer strips. Magazine of Concrete Research, 55(3), pp. 279-288.

http://dx.doi.org/10.1680/macr.2003.55.3.279

Iovinella, I.; Prota, A.; Mazzotti, C., 2013.Influence of surface roughness on the bond of FRP laminates to concrete. Construction and Building Materials, 40, pp. 533-542. http://dx.doi.org/10.1016/j.conbuildmat.2012.09.112

Lamanna, A. J.; Bank, L. C.; Scott, D. W., 2004. Flexural strengthening of RC beams by mechanically attaching FRP Strips, Journal of Composites for Construction, 8(3), pp. 203-210. http://dx.doi.org/10.1061/(ASCE)10900268(2004)8:3(203)

Li, L.; Guo, Y.; Liu, F., 2008. Test analysis for FRC beams strengthened with externally bonded FRP sheets. Construction and Building Materials, 22(3), pp. 315-323. http://dx.doi.org/10.1016/j.conbuildmat.2006.08.016

Lu, X. Z.; Jiang, J. J.; Teng, J. G.; Ye, L. P., 2006. Finite element simulation of debonding in FRP-to-concrete bonded joints, Construction and Building Materials, 20(6), pp. 412-424. http://dx.doi.org/10.1016/j.conbuildmat.2005.01.033

Mazzotti, C.; Savoia, M.; Ferracuti, B., 2008. An experimental study on delamination of FRP plates bonded to concrete, Construction and Building Materials, 22(7), pp. 1409-1421. http://dx.doi.org/10.1016/j.conbuildmat.2007.04.009

Mostofinejad, D.; Shameli, S. M., 2013. Externally bonded reinforcement in grooves (EBRIG) technique to postpone debonding of FRP sheets in strengthened concrete beams. Construction and Building Materials, 38, pp. 751-758. http://dx.doi.org/10.1016/j.conbuildmat.2012.09.030

Niu, H.; Wu, Z., 2006. Effects of FRP concrete interface bond properties on the performance of RC beams strengthened in flexure with externally bonded FRP sheets. Journal of Materials in Civil Engineering, 18(5), pp. 723-731.
http://dx.doi.org/10.1061/(ASCE)0899-1561(2006)18:5(723)

Pan, J.; Leung, C. K. Y., 2007 a. Debonding along the FRPconcrete interface under combined pulling/peeling effects. Engineering Fracture Mechanics, 74(1-2), pp. 132-150. http://dx.doi.org/10.1016/j.engfracmech.2006.01.022

Pan, J.; Leung, C. K. Y., 2007 b. Effect of concrete composition on frp concrete bond capacity. Journal of Composites for Construction, 11(6), pp. 611-618.

http://dx.doi.org/10.1061/(ASCE)1090-0268(2007)11:6(611)

Perera, R.; Recuero, A.; De Diego, A.; Lopez, C., 2004. Adherence analysis of fiber-reinforced polymer strengthened RC beams. Computers \& Structures, 82(23-26), pp. 1865-1873. http://dx.doi.org/10.1016/j.compstruc.2004.03.060

Pham, H. B.; Al-Mahaidi, R.; Saouma, V., 2006. Modelling of CFRP-concrete bond using smeared and discrete cracks. Composite Structures, 75(1-4), pp. 145-150. http://dx.doi.org/10.1016/j.compstruct.2006.04.039

Pham, H. B.; Al-Mahaidi, R., 2007. Modelling of CFRPconcrete shear-lap tests. Construction and Building Materials, 21(4), pp. 727-735.

http://dx.doi.org/10.1016/j.conbuildmat.2006.06.012

Ramos, G.; Casas, J. R.; Alarcón, A., 2004. Repair and strengthening of segmental bridges using carbon fibers, Engineering Structures, 26(5), pp. 609-618. http://dx.doi.org/10.1016/j.engstruct.2003.12.008

Ramos, G.; Casas, J. R.; Alarcon, A., 2006. Normalized test for prediction of debonding failure in concrete elements strengthened with CFRP. Journal of Composites for Construction, 10(6), pp. 509-519. http://dx.doi.org/10.1061/(ASCE)1090-0268(2006)10:6(509)

Saxena, P.; Toutanji, H.; Noumowe, A., 2008. Failure analysis of FRP strengthened RC beams. Journal of Composites for Construction, 12(1), pp. 2-14. http://dx.doi.org/10.1061/(ASCE)1090-0268(2008)12:1(2)

Schilde, K.; Seim, W., 2007. Experimental and numerical investigations of bond between CFRP and concrete. Construction and Building Materials, 21(4), pp.709-726. http://dx.doi.org/10.1016/j.conbuildmat.2006.06.006

Skuturna, T.; Valivonis, J.; Vainiūnas, P.; Marčiukaitis, G.; Daugevičius, M., 2008. Analysis of deflections of bridge girders strengthened by carbon fiber reinforcement. The Baltic Journal of Road and Bridge Engineering, 3(3), pp. 145-151. http://dx.doi.org/10.3846/1822427X.2008.3.145-151

Smith, S. T.; Teng, J. G., 2002a. FRP-strengthened RC beams. I: review of debonding strength models. Engineering Structures, 24(4), pp.385-395. http://dx.doi.org/10.1016/S0141-0296(01)00105-5

Smith, S. T.; Teng, J. G., 2002b. FRP-strengthened RC beams. II: assessment of debonding strength models. Engineering Structures, 24(4), pp. 397-417. http://dx.doi.org/10.1016/S0141-0296(01)00106-7

Subramaniam, K. V.; Carloni, C.; Nobile, L., 2007. Width effect in the interface fracture during shear debonding of FRP sheets from concrete. Engineering Fracture Mechanics, 74(4), pp. 578-594.

http://dx.doi.org/10.1016/j.engfracmech.2006.09.002

Thomsen, H.; Spacone, E.; Limkatanyu, S.; Camata, G., 2004. Failure mode analyses of reinforced concrete beams strengthened in flexure with externally bonded fiber-reinforced polymers. Journal of Composites for Construction, 8(2), pp. 123-131. http://dx.doi.org/10.1061/(ASCE)1090$\underline{0268(2004) 8: 2(123)}$ 
Trapko, W.; Trapko, T., 2012. Load-bearing capacity of compressed concrete elements subjected to repeated load strengthened with CFRP materials. Journal of Civil Engineering and Management, 18(2), pp. 590-599. http://dx.doi.org/10.3846/13923730.2012.701664

Ueda, T.; Jianguo, D., 2005. Interface bond between FRP sheets and concrete substrates: properties, numerical modeling and roles in member behaviour. Progress in Structural Engineering and Materials, 7(1), pp. 27-43. http://dx.doi.org/10.1002/pse.187

Valivonis, J.; Skuturna, T., 2007. Cracking and strength of reinforced concrete structures in flexure strengthened with carbon fibre laminates. Journal of Civil Engineering and Management, 13(4), pp. 317-323.

Wang, Y. C.; Lee, M. G.; Chen, B. C., 2007. Experimental study of FRP-strengthened RC bridge girders subjected to fatigue loading. Composite Structures, 81(2), pp. 491-498. http://dx.doi.org/10.1016/j.compstruct.2006.09.012

Xie, J.; Hu, R., 2013. Experimental study on rehabilitation of corrosion-damaged reinforced concrete beams with carbon fiber reinforced polymer. Construction and Building Materials, 38, pp. 708-716.

http://dx.doi.org/10.1016/j.conbuildmat.2012.09.023

Yail, J.; Kim, Y.J.; Hossain, M.; Zhang, J., 2013. A probabilistic investigation into deterioration of CFRPconcrete interface in aggressive environments. Construction and Building Materials, 41, pp. 49-59.

http://dx.doi.org/10.1016/j.conbuildmat.2012.11.101

Yuan, H.; Teng, J. G.; Seracino, R.; Wu, Z. S.; Yao, J., 2004. Full-range behavior of FRP-to-concrete bonded joints. Engineering Structures, 26(5), pp. 553-565. http://dx.doi.org/10.1016/j.engstruct.2003.11.006 